\title{
Calpains are activated by photodynamic therapy but do not contribute to apoptotic tumor cell death
}

\author{
Ramiro D. Almeida, Edgar R. Gomes, Arsélio P. Carvalho, Carlos B. Duarte* \\ Center for Neuroscience and Cell Biology, Department of Zoology, University of Coimbra, 3004-517 Coimbra, Portugal
}

Received 17 March 2004; received in revised form 30 June 2004; accepted 7 July 2004

\begin{abstract}
Photodynamic therapy (PDT) of cancer is a promising technique based on the formation of singlet oxygen following irradiation of a sensitizer with visible light. In the present work we investigated the role of calpains in PDT, using the human lymphoblastoid CCRF-CEM cells and bisulfonated aluminum phthalocyanine $\left(\mathrm{AlPcS}_{2}\right)$ as a sensitizer. Photosensitization induced apoptotic cell death and a time-dependent activation of calpains, as determined using the fluorogenic substrate succinyl-Leu-Leu-Val-Tyr-7-amido-4-methylcoumarin (SLLVY-AMC). However, inhibition of calpains with calpain inhibitor II or with PD 150606 did not affect the demise process. The results indicate that although calpains are activated in PDT, they do not play a major role in tumor cell death.
\end{abstract}

(C) 2004 Elsevier Ireland Ltd. All rights reserved.

Keywords: Photodynamic therapy; Calpains; Caspases; Apoptosis

\section{Introduction}

Photodynamic therapy (PDT) of cancer is based on the tumor-specific accumulation of a photosensitizer, followed by irradiation with visible light, which induces cell death and tumor ablation. Photofrin, the first photosensitizer approved for human use, has been successfully employed in the treatment of lung, esophageal, cervical, bladder and gastric tumors, but a second generation of photosensitizers have attained approval for treatment of various cancers in Europe

\footnotetext{
* Corresponding author. Tel.: +351-239-480-209; fax: + 351239-480-208.

E-mail address: cbduarte@ci.uc.pt (C.B. Duarte).
}

and Japan [1-3]. PDT induces a rapid apoptotic response in tumor cells (e.g. [4,5]), and the release of cytochrome $\mathrm{C}$ from mitochondria and consequent activation of a cascade of apoptosis-mediating caspases have been described in photosensitized cells (reviewed in Refs. [6,7]). However, the mechanism leading to the induction of apoptosis in photosensitized cells is not fully understood.

Calpains are ubiquitous $\mathrm{Ca}^{2+}$-dependent intracellular cysteine proteases. Two major calpains were identified, $\mu$-calpain (calpain I) and m-calpain (calpain II), which differ in the $\mathrm{Ca}^{2+}$ concentration required for maximal activity. Both classes of calpains are regulated by a specific endogenous inhibitor, calpastatin (reviewed in Ref. [8]). Although calpain activation during apoptosis has been observed in 
a number of cell culture and in vivo models, the role of these proteases in the demise process is controversial. In fact, inhibition of calpains was shown to have no effect (e.g. $[9,10])$, to increase (e.g. [10-14]) and to reduce (e.g. [10,15-19]) apoptosis. Even in the same cell line the role of calpains in apoptosis can vary depending on the type of insult (e.g. [10]), suggesting that the diversity of effects that have been reported may arise, at least in part, from differences in the initial intracellular signals generated by the toxic insult. Another level of complexity may result from the cross-talk between the caspase and calpain proteolytic systems [13,20-25].

Photodynamic treatment of various tumor cell types has been shown to raise the $\left[\mathrm{Ca}^{2+}\right]_{\mathrm{i}}$, due to $\mathrm{Ca}^{2+}$ entry through ion channels (e.g. [26]), release of $\mathrm{Ca}^{2+}$ sequestered in internal stores (e.g. [27-29]), and/or activation of ion exchange mechanisms ([30]; see also Ref. [7] for a review). The increase in the $\left[\mathrm{Ca}^{2+}\right]_{\mathrm{i}}$ was shown to play an important role in the demise process, using various sensitizers and cell types [31,32]. Since $\mathrm{Ca}^{2+}$ activates calpains, we investigated a putative role for these proteases in PDT, using CCRF-CEM cells and bisulfonated aluminum phthalocyanine $\left(\mathrm{AlPcS}_{2}\right)$ as a sensitizer. We have previously shown that photosensitization of CCRF-CEM cells with AlPcS ${ }_{2}$ induces cell death by apoptosis, characterized by chromatin condensation, cleavage of caspases -3 and -9 , and DNA fragmentation [5].

\section{Materials and methods}

\subsection{Materials}

The human lymphoblastoid CCRF-CEM cells were obtained from American Type Culture Collection (Manassas, VA), and fetal calf serum was from Biochrom (Berlin, Germany). $\mathrm{AlPcS}_{2}$ was a gift from Dr Johan E. Van Lier (University of Sherbrooke, Quebec, Canada). Ionomycin, PD 150606 and calpain inhibitor II were purchased from Calbiochem (La Jolla, CA). SYTO-13 and propidium iodide were from Molecular Probes (Leiden, The Netherlands) and Carbobenzoxy-Val-Ala-Asp(Ome)-FMK (Z-VADFMK) was from Enzyme Systems Products (Livermore, CA). Suc-Leu-Leu-Val-Tyr-AMC (SLLVY-AMC) was purchased from Bachem (Bubendorf, Switzerland). All other chemicals were from Sigma (Sintra, Portugal) or Merck (Darmstadt, Germany).

\subsection{Cell culture}

CCRF-CEM cells were cultured in RPMI-1640 medium supplemented with $10 \%$ fetal calf serum, $23.8 \mathrm{mM} \mathrm{NaHCO} 3$ and penicillin-streptomycin $(50 \mathrm{U} / \mathrm{ml}$ and $50 \mu \mathrm{g} / \mathrm{ml})$, in a $95 \%$ air and $5 \% \mathrm{CO}_{2}$ atmosphere.

\subsection{PDT treatment}

Cells $\left(0.5 \times 10^{6}\right.$ cells $\left./ \mathrm{ml}\right)$ were incubated with $5 \mu \mathrm{M} \mathrm{AlPcS} 2$ for $18 \mathrm{~h}$. After centrifugation the pellet was resuspended in fresh culture medium, at the initial concentration. Cells were then irradiated with visible light using a cut off filter $(<600 \mathrm{~nm})$, with a fluence rate of $30 \mathrm{~mW} / \mathrm{cm}^{2}$, and a total light dose of $15 \mathrm{~J} / \mathrm{cm}^{2}$, as previously described [33]. The cells were then centrifuged and incubated in culture medium for $3 \mathrm{~h}$ before quantification of cell death or calpain activity.

\subsection{Quantification of apoptotic cell death}

Cells were washed and resuspended in $\mathrm{Na}^{+}$salt solution (in mM: $140 \mathrm{NaCl}, 5 \mathrm{KCl}, 1 \mathrm{MgCl}_{2}, 1 \mathrm{CaCl}_{2}$, 5.5 Glucose, $15 \quad N$-2-hydroxyethylpiperazine- $N^{\prime}-2$ ethanesulfonic acid [HEPES], pH 7.4) supplemented with $200 \mathrm{nM}$ SYTO-13 and $1.6 \mu \mathrm{g} / \mathrm{ml}$ propidium iodide. Apoptotic nuclei were scored under a fluorescence microscope using a triple-wavelength filter set (XF 63; Omega Optical, Brattleboro, VT).

\subsection{Measurement of calpain activity}

The cells $\left(1 \times 10^{6}\right)$ were centrifuged, and the pellet was then resuspended in $2 \mathrm{ml}$ of $\mathrm{Na}^{+}$medium. The fluorogenic substrate of calpains SLLVY-AMC was added to the cuvette, at a final concentration of $200 \mu \mathrm{M}$, and the cell suspensions were then maintained at $37^{\circ} \mathrm{C}$. The AMC fluorescence was measured every $5 \mathrm{~min}$, at $37^{\circ} \mathrm{C}$, using a SPEX Fluoromax spectrofluorometer $\left(\lambda_{\mathrm{ex}}=380 \mathrm{~nm} ; \lambda_{\mathrm{em}}=460 \mathrm{~nm}\right)$. 


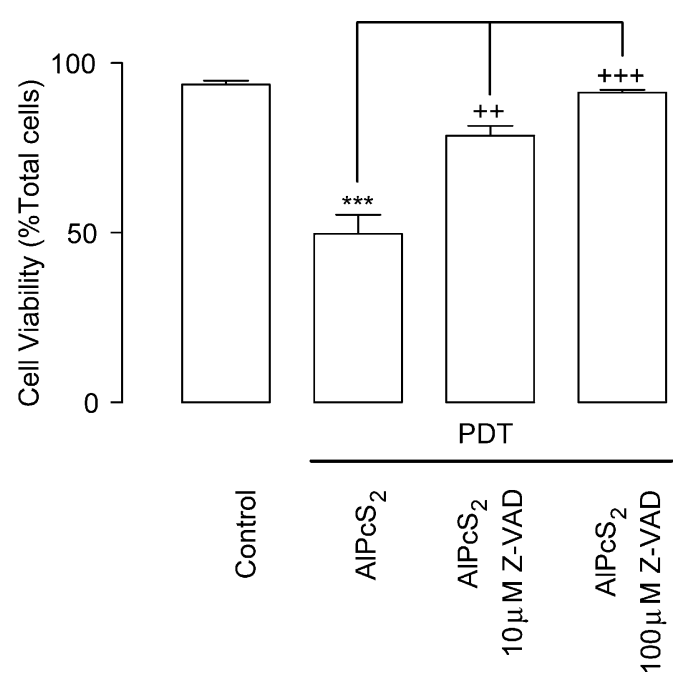

Fig. 1. Inhibition of PDT-induced apoptotic death by the caspase inhibitor Z-VAD-FMK. CCRF-CEM cells were subjected or not (control) to PDT with $\mathrm{AlPcS}_{2}$, as indicated in the methods section, and apoptotic morphology was evaluated by double staining, with propidium iodide and SYTO-13, $3 \mathrm{~h}$ after irradiation. Where indicated the cells were pre-incubated with 10 or $100 \mu \mathrm{M} \mathrm{Z}$-VAD-FMK, for $1 \mathrm{~h}$, before photosensitization, and maintained in the presence of the inhibitor until cell death was measured. The results are the average \pm SEM of three independent experiments. Statistical significance was determined using the One Way ANOVA followed by the Tukey's multiple comparison test: $* * * P<0.001$, as compared with the control, or ${ }^{++} P<0.01$ and ${ }^{+++} P<0.001$, as compared with photosensitized cells in the absence of Z-VAD-FMK.

\subsection{Statistical analysis}

Statistical significance was determined using the two-tailed Student's $t$-test or the One Way ANOVA followed by the Tukey's multiple comparison, as indicated.

\section{Results}

The role of capains in cell induced by PDT was investigated using CCRF-CEM cells, and $\mathrm{AlPcS}_{2}$ as a sensitizer. The cells were pre-incubated with the sensitizer for $18 \mathrm{~h}$ before irradiation, and cell death was measured $3 \mathrm{~h}$ after irradiation with a fluence rate of $30 \mathrm{~mW} / \mathrm{cm}^{2}$, and a total light dose of $15 \mathrm{~J} / \mathrm{cm}^{2}$, by double staining with SYTO-13 and propidium iodide. Under these conditions we observed that about $50 \%$ (Fig. 1, AlPcS ${ }_{2}$ ) of the cells exhibited the characteristic apoptotic morphology. The number of necrotic cells was less than 5\%, as in the control (not shown). Incubation of the cells with a general caspase inhibitor, Z-VAD-FMK [34], prevented cell death in a dose-dependent manner. The number of apoptotic cells found when photosensitization was performed in the presence of $100 \mu \mathrm{M} \mathrm{Z-VAD-FMK}$ was not significantly different from the control $(P>0.05)$.

In order to determine whether PDT with $\mathrm{AlPcS}_{2}$ increase calpain activity in CCRF-CEM cells we used the fluorogenic calpain substrate SLLVY-AMC $[35,36]$. Control experiments showed that the $\mathrm{Ca}^{2+}$ ionophore ionomycin $(10 \mu \mathrm{M})$ rapidly increased the rate of hydrolysis of SLLVY-AMC, as expected for a calpain substrate (Fig. 2A). The activity of calpains in photosensitized cells was measured by the rate of SLLVY-AMC cleavage, at different periods of time following irradiation. In each case the enzyme activity was followed for at least $20 \mathrm{~min}$ (Fig. 2C) and the results show that the rate of substrate hydrolysis increased upon photosensitization, after a lag-phase of about $2 \mathrm{~h}$ (Fig. 2B). Inhibition of calpains with Calpain Inhibitor II (CI II; [37]) substantially reduced the hydrolysis of the peptide by photosensitized cells, to levels below those determined in control cells (Fig. 2D). Control experiments showed that irradiation of cells free of $\mathrm{AlPcS}_{2}$ did not affect SLLVY-AMC cleavage $(P>0.05)$, but the enzyme activity under these conditions was still sensitive to the effect of CI II. These results indicate that there is a certain level of calpain activity under resting conditions.

The role of calpains in PDT was evaluated using the calpain inhibitors CI II and PD150606 [36]. None of the inhibitors affected the death of CCRF-CEM cells sensitized with $\mathrm{AlPcS}_{2}$ when measured $3 \mathrm{~h}$ after the irradiation (Fig. 3), although at this point a significant increase in the cleavage of the calpain subtrate was observed (Fig. 2B).

\section{Discussion}

In this work we show that photosensitization of CCRF-CEM cells with $\mathrm{AlPcS}_{2}$ activated calpains and rapidly induced apoptotic cell death, but inhibition of calpains did not affect significantly the demise process. 

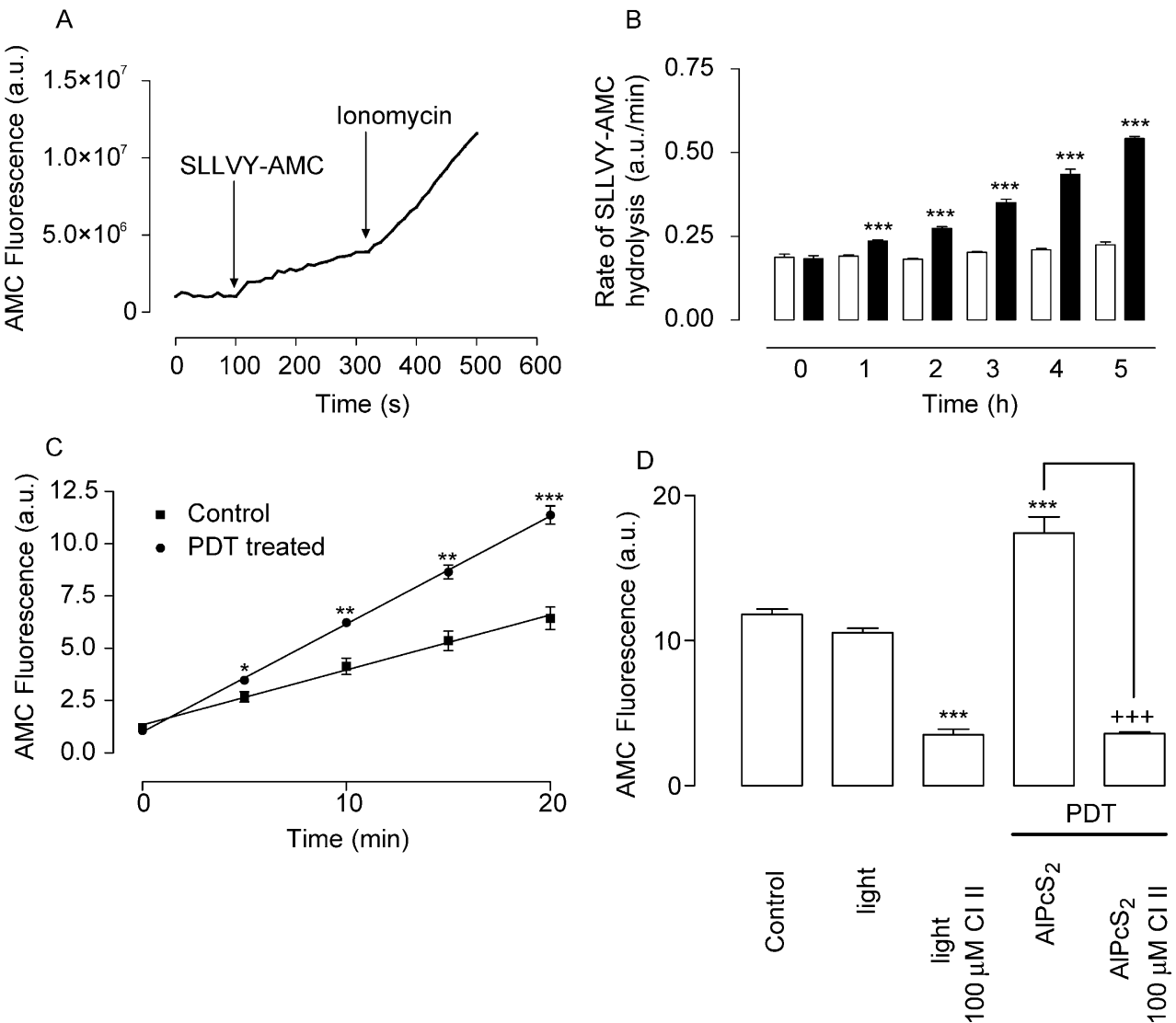

Fig. 2. PDT with $\mathrm{AlPcS}_{2}$ stimulates the cleavage of the calpain substrate SLLVY-AMC. (A) After addition of SLLVY-AMC (200 $\mu$ M) CCRFCEM cells were stimulated with $10 \mu \mathrm{M}$ ionomycin, and the fluorescence of the AMC group cleaved from the substrate was measured as indicated in the methods section. (B) Control or photosensitized cells $\left(\mathrm{AlPcS}_{2}\right)$ were incubated in culture medium, for the indicated period of time, before measuring SLLVY-AMC cleavage activity. AMC fluorescence was measured every 5 min, and the cleavage of the substrate was linear over a $20 \mathrm{~min}$ period. The results show the slope of the straight line resulting from the fit of experimental data points of SLLVY-AMC cleavage, and are the average \pm SEM of 3-5 independent experiments. Panel $\mathrm{C}$ shows the changes in fluorescence intensity in suspensions of control and PDT-treated cells, $5 \mathrm{~h}$ after photosensitization, and the results are the average \pm SEM of 4 independent experiments. (D) AMC fluorescence (a.u.) resulting from the cleavage of SLLVY-AMC by control cells, irradiated (light) or not, and by cells subjected to PDT with $\mathrm{AlPcS}_{2}$. Enzyme activity was measured $3 \mathrm{~h}$ after irradiation. Incubation with the substrate was performed for 15 min. Where indicated the cells were pre-incubated with calpain inhibitor II before irradiaton, for $2 \mathrm{~h}$, and the inhibitor was also added to the incubation medium after irradiation. The results are the average \pm SEM of 3-5 independent experiments. Statistical significance was determined using the One Way ANOVA followed by the Tukey's multiple comparison test (D) or the two-tailed Student's $t$-test $(\mathrm{B}, \mathrm{C}) .{ }^{*} P<0.05$, $* * P<0.01$, $* * * P<0.001$, as compared with the control. ${ }^{++} P<0.001$, as compared with photosensitized cells in the absence of CI II.

The rapid induction of apoptosis detected here by changes in the nuclear morphology is in agreement with our previous findings, showing that photosensitization of CCRF-CEM cells with $\mathrm{AlPcS}_{2}$ induces cell death by apoptosis, characterized by chromatin condensation, cleavage of caspases- 3 and -9 , and DNA fragmentation [5]. This cascade of events may be subjected to regulation by calpains at different levels. Indeed, caspase-9 is truncated by calpains, giving rise to the $\mathrm{p} 35$ polypeptide that has no ability to activate caspase-3 [22,23]. Calpains also cleave APAF-1, which forms the apoptosome together with dATP, cytochrome $\mathrm{C}$ released from the mitochondria and caspase-9 [38]. Furthermore, calpain-mediated cleavage of caspase- 3 to a p30 polypeptide enhanced its activity in one case and reduced activation in another [22,24,25]. Although these evidences indicate that calpains may act as negative regulators of nuclear 
A
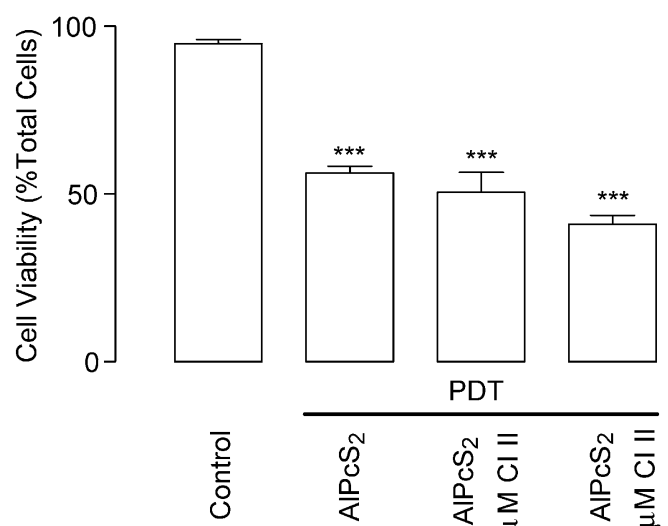

PDT

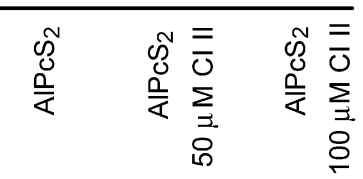

B

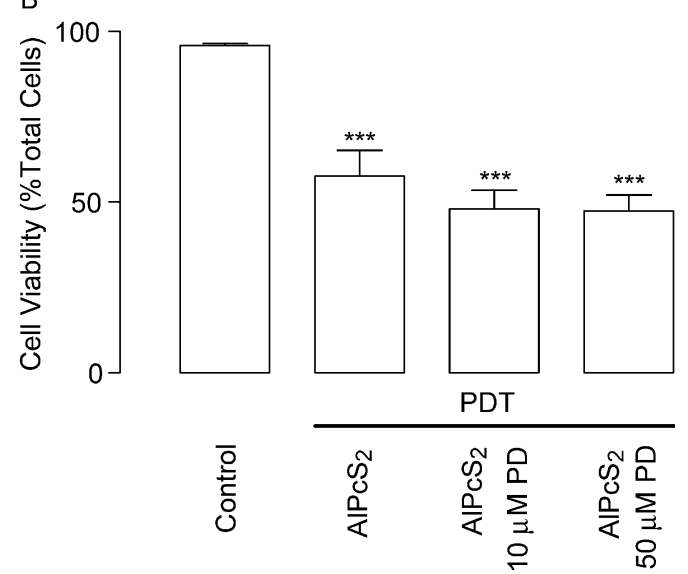

Fig. 3. Calpain inhibitors have no effect on PDT-induced apoptotic cell death. The cells were photosensitized with $\mathrm{AlPcS}_{2}$ as indicated in the methods section, and where indicated were pre-incubated with calpain inhibitor II (50 or $100 \mu \mathrm{M})(\mathrm{A})$ or with PD $150606(10$ or $50 \mu \mathrm{M}$ ) for $2 \mathrm{~h}$ before irradiation (B). When the effect of calpain inhibitors was tested they were also present during photosensitization as well as during the following $3 \mathrm{~h}$, before measuring cell death. The results are the average \pm SEM of $4-6$ independent experiments. $* * * P<0.001$, as compared with the control.

apoptotic changes, that occur downstream of caspase activation, our results show that this is not the case in CCRF-CEM cells sensitized with $\mathrm{AlPcS}_{2}$. The lack of effect of calpains on the demise process may be due to an insufficient activation of the enzyme and/or to the localization of calpains within the cells, which may be unfavorable to interaction with proteins of the apoptotic pathway.

The lack of effect of calpain inhibitors on PDTinduced apoptotic cell death reported here also contrasts with results showing that calpain plays an active role in apoptosis [10,15-19]. Cleavage of $\mathrm{X}$-linked inhibitor of apoptosis (XIAP) by calpains produces fragments that are unable to inhibit caspase3 , and this was suggested to contribute to the inhibition of apoptosis in neurophils [14]. Calpains may also contribute to apoptosis by cleaving Bid, thereby generating a fragment able to trigger cytochrome C release from mitochondria [18,19,39]. Furthermore, calpains cleave Bax at its N-terminal region, generating a potent pro-apoptotic fragment, and one study has reported a reduction in cell death when Bax cleavage was prevented with a calpain inhibitor [17]. In contrast, although inhibition of calpains prevented Bax cleavage in neurons and HL-60 cells, stimulated with the apoptotic agents staurosporin and 9-AC (topoisomerase I inhibitor), respectively, it was without effect on cell death $[9,40]$. However, Bax protein levels remained unaltered in various cell lines subjected to PDT with the silicon phthalocyanine Pc4 [41], 9-capronyloxy-tetrakis (methoyxyethyl) porphycene (CPO), meta-tetrahydroxyphenyl chlorin ( $m$ THPC), tin etiopurpurin [42] and verteporfin [43]. Also, photosensitization of the $\mathrm{T}$ cell hybridoma PC60R1R2 with hypericin did not change Bid protein levels [44]. Therefore, cleavage of Bid and Bax by calpains does not appear to play an important role in PDT.

Calpains are proteases activated by $\mathrm{Ca}^{2+}$, and since PDT increases the $\left[\mathrm{Ca}^{2+}\right]_{\mathrm{i}}[26-30]$ this mechanism is likely to contribute to the increase in the activity of the enzyme observed in the present work in CCRF-CEM cells photosensitized with $\mathrm{AlPcS}_{2}$. However, there is also evidence that caspases, including caspase-3, can promote calpain activity through cleavage of calpastatin, the endogenous protein inhibitor of calpains [20,21,45]. Since caspase- 3 is activated in CCRF-CEM cells subjected to PDT with $\mathrm{AlPcS}_{2}$ [5] this may contribute, at least in part, to the observed activation of calpains.

$\mathrm{AlPcS}_{2}$, the photosensitizer used in the present work, has a diffuse distribution within the cells, probably in the mitochondria [46]. Cell damage is thought to arise from the action of reactive oxygen species, primarily singlet oxygen, formed upon interaction of light with the sensitizer. Since singlet oxygen has a short half-life in cells, its intracellular targets are close to the sites where the sensitizer is 
located [1]. Therefore, it is not surprising that PDT with $\mathrm{AlPcS}_{2}$ induces a rapid apoptotic response through the mitochondria mediated pathway [5]. Since the type of cellular response triggered by activation of the photosensitizers depends on their intracellular localization, it cannot be excluded a possible role for calpains in apoptotic cell death in PDT using other compounds.

\section{Acknowledgements}

This work was supported by Fundação para a Ciência e a Tecnologia (Portugal) and FEDER.

\section{References}

[1] T.J. Dougherty, C.J. Gomer, B.W. Henderson, G. Jori, D. Kessel, M. Korbelik, et al., Photodynamic therapy, J. Natl. Cancer Inst. 90 (1998) 889-905.

[2] R. Ackroyd, C. Kelty, N. Brown, M. Reed, The history of photodetection and photodynamic therapy, Photochem. Photobiol. 74 (2001) 656-669.

[3] T.J. Dougherty, An update on photodynamic therapy applications, J. Clin. Laser Med. Surg. 20 (2002) 3-7.

[4] Y. Luo, C.K. Chang, D. Kessel, Rapid initiation of apoptosis by photodynamic therapy, Photochem. Photobiol. 63 (1996) 528-534.

[5] E.R. Gomes, R.D. Almeida, A.P. Carvalho, C.B. Duarte, Nitric oxide modulates tumor cell death induced by photodynamic therapy through a cGMP-dependent mechanism, Photochem. Photobiol. 76 (2002) 423-430.

[6] N.L. Oleinick, R.L. Morris, I. Belichenko, The role of apoptosis in response to photodynamic therapy: what, where, why, and how, Photochem. Photobiol. Sci. 1 (2002) 1-21.

[7] R.D. Almeida, B.J. Manadas, A.P. Carvalho, C.B. Duarte, Intracellular signaling mechanisms in photodynamic therapy, BBA-Rev. Cancer 2004; in press.

[8] D.E. Goll, V.F. Thompson, H. Li, W. Wei, J. Cong, The calpain system, Physiol. Rev. 83 (2003) 731-801.

[9] D.E. Wood, A. Thomas, L.A. Devi, Y. Berman, R.C. Beavis, J.C. Reed, E.W. Newcomb, Bax cleavage is mediated by calpain during drug-induced apoptosis, Oncogene 17 (1998) 1069-1078.

[10] T. Lu, Y. Xu, M.T. Mericle, R.L. Mellgren, Participation of the conventional calpains in apoptosis, Biochim. Biophys. Acta 1590 (2002) 16-26.

[11] D.M. Zhu, F.M. Uckun, Calpain inhibitor II induces caspasedependent apoptosis in human acute lymphoblastic leukemia and non-Hodgkin's lymphoma cells as well as some solid tumor cells, Clin. Cancer Res. 6 (2000) 2456-2463.

[12] J.M. Witkowski, E. Zmuda-Trzebiatowska, J.M. Swiercz,
M. Cichorek, H. Ciepluch, K. Lewandowski, et al., Modulation of the activity of calcium-activated neutral proteases (calpains) in chronic lymphocytic leukemia (B-CLL) cells, Blood 100 (2002) 1802-1809.

[13] R.W. Neumar, Y.A. Xu, H. Gada, R.P. Guttmann, R. Siman, Cross-talk between calpain and caspase proteolytic systems during neuronal apoptosis, J. Biol. Chem. 278 (2003) 14162-14167.

[14] S. Kobayashi, K. Yamashita, T. Takeoka, T. Ohtsuki, Y. Suzuki, R. Takahashi, et al., Calpain-mediated X-linked inhibitor of apoptosis degradation in neutrophil apoptosis and its impairment in chronic neutrophilic leukemia, J. Biol. Chem. 277 (2002) 33968-33977.

[15] M.K. Squier, A.C. Miller, A.M. Malkinson, J.J. Cohen, Calpain activation in apoptosis, J. Cell. Physiol. 159 (1994) 229-237.

[16] A. Ruiz-Vela, G. Gonzalez de Buitrago, A.C. Martinez, Implication of calpain in caspase activation during B cell clonal deletion, EMBO J 18 (1999) 4988-4998.

[17] G. Gao, Q.P. Dou, N-terminal cleavage of bax by calpain generates a potent proapoptotic $18-\mathrm{kDa}$ fragment that promotes bcl-2-independent cytochrome $\mathrm{C}$ release and apoptotic cell death, J. Cell. Biochem. 80 (2000) 53-72.

[18] A. Mandic, K. Viktorsson, L. Strandberg, T. Heiden, J. Hansson, S. Linder, M.C. Shoshan, Calpain-mediated Bid cleavage and calpain-independent Bak modulation: two separate pathways in cisplatin-induced apoptosis, Mol. Cell. Biol. 22 (2002) 3003-3013.

[19] M. Chen, D.J. Won, S. Krajewski, R.A. Gottlieb, Calpain and mitochondria in ischemia/reperfusion injury, J. Biol. Chem. 277 (2002) 29181-29186.

[20] M.I. Porn-Ares, A. Samali, S. Orrenius, Cleavage of the calpain inhibitor, calpastatin, during apoptosis, Cell Death Differ. 5 (1998) 1028-1033.

[21] K.K. Wang, R. Posmantur, R. Nadimpalli, R. Nath, P. Mohan, R.A. Nixon, et al., Caspase-mediated fragmentation of calpain inhibitor protein calpastatin during apoptosis, Arch. Biochem. Biophys. 356 (1998) 187-196.

[22] B.T. Chua, K. Guo, P. Li, Direct cleavage by the calciumactivated protease calpain can lead to inactivation of caspases, J. Biol. Chem. 275 (2000) 5131-5135.

[23] S. Lankiewicz, C. Marc, N. Luetjens, A.J. Truc Bui, M. Krohn, G.M. Poppe, et al., Activation of calpain I converts excitotoxic neuron death into a caspase-independent cell death, J. Biol. Chem. 275 (2000) 17064-17071.

[24] K.M. McGinnis, M.E. Gnegy, Y.H. Park, N. Mukerjee, K.K. Wang, Procaspase-3 and poly(ADP)ribose polymerase (PARP) are calpain substrates, Biochem. Biophys. Res. Commun. 263 (1999) 94-99.

[25] K. Blomgren, C. Zhu, X. Wang, J.O. Karlsson, A.L. Leverin, B.A. Bahr, C. Mallard, H. Hagberg, Synergistic activation of caspase- 3 by $\mathrm{m}$-calpain after neonatal hypoxia-ischemia: a mechanism of pathological apoptosis?, J. Biol. Chem. 276 (2001) 10191-10198.

[26] P.G. Joshi, K. Joshi, S. Mishra, N.B. Joshi, $\mathrm{Ca}^{2+}$ influx induced by photodynamic action in human cerebral glioma (U87 MG) cells: possible involvement of a calcium channel, Photochem. Photobiol. 60 (1994) 244-248. 
[27] M.L. Agarwal, H.E. Larkin, S.I. Zaidi, H. Mukhtar, N.L. Oleinick, Phospholipase activation triggers apoptosis in photosensitized mouse lymphoma cells, Cancer Res. 53 (1993) 5897-5902.

[28] A. Hubmer, A. Hermann, K. Uberriegler, B. Krammer, Role of calcium in photodynamically induced cell damage of human fibroblasts, Photochem. Photobiol. 64 (1996) 211-215.

[29] D.J. Granville, D.O. Ruehlmann, J.C. Choy, B.A. Cassidy, D.W. Hunt, C. van Breemen, B.M. McManus, Bcl-2 increases emptying of endoplasmic reticulum $\mathrm{Ca}^{2+}$ stores during photodynamic therapy-induced apoptosis, Cell Calcium. 30 (2001) 343-350.

[30] K.G. Specht, M.A. Rodgers, Plasma membrane depolarization and calcium influx during cell injury by photodynamic action, Biochim. Biophys. Acta 1070 (1991) 60-68.

[31] O. Inanami, A. Yoshito, K. Takahashi, W. Hiraoka, M. Kuwabara, Effects of BAPTA-AM and forskolin on apoptosis and cytochrome $\mathrm{c}$ release in photosensitized Chinese hamster V79 cells, Photochem. Photobiol. 70 (1999) 650-655.

[32] M. Ogata, O. Inanami, M. Nakajima, T. Nakajima, W. Hiraoka, M. Kuwabara, $\mathrm{Ca}^{2+}$-dependent and caspase-3-independent apoptosis caused by damage in Golgi apparatus due to 2,4,5,7tetrabromorhodamine 123 bromide-induced photodynamic effects, Photochem. Photobiol. 78 (2003) 241-247.

[33] E.R. Gomes, T. Cruz, C.F. Lopes, A.P. Carvalho, C.B. Duarte, Photosensitization of lymphoblastoid cells with phthalocyanines at different saturating incubation times, Cell Biol. Toxicol. 15 (1999) 249-260.

[34] M. Garcia-Calvo, E.P. Peterson, B. Leiting, R. Ruel, D.W. Nicholson, N.A. Thornberry, Inhibition of human caspases by peptide-based and macromolecular inhibitors, J. Biol. Chem. 273 (1998) 32608-32613.

[35] T. Sasaki, T. Kikuchi, N. Yumoto, N. Yoshimura, T. Murachi, Comparative specificity and kinetic studies on porcine calpain I and calpain II with naturally occurring peptides and synthetic fluorogenic substrates, J. Biol. Chem. 259 (1984) 1248912494.

[36] K.K. Wang, R. Nath, A. Posner, K.J. Raser, M. BurokerKilgore, I. Hajimohammadreza, et al., An alpha-mercaptoacrylic acid derivative is a selective nonpeptide cellpermeable calpain inhibitor and is neuroprotective, Proc. Natl. Acad. Sci. USA 93 (1996) 6687-6692.
[37] T. Sasaki, M. Kishi, M. Saito, T. Tanaka, N. Higuchi, E. Kominami, N. Katunuma, T. Murachi, Inhibitory effect of di- and tripeptidyl aldehydes on calpains and cathepsins, J. Enzyme Inhib. 3 (1990) 195-201.

[38] C. Reimertz, D. Kogel, S. Lankiewicz, M. Poppe, J.H. Prehn, $\mathrm{Ca}^{2+}$-induced inhibition of apoptosis in human SH-SY5Y neuroblastoma cells: degradation of apoptotic protease activating factor-1 (APAF-1), J. Neurochem. 78 (2001) 1256-1266.

[39] M. Chen, H. He, S. Zhan, S. Krajewski, J.C. Reed, R.A. Gottlieb, Bid is cleaved by calpain to an active fragment in vitro and during myocardial ischemia/reperfusion, J. Biol. Chem. 276 (2001) 30724-30728.

[40] W.S. Choi, E.H. Lee, C.W. Chung, Y.K. Jung, B.K. Jin, S.U. Kim, et al., Cleavage of Bax is mediated by caspasedependent or -independent calpain activation in dopaminergic neuronal cells: protective role of Bcl-2, J. Neurochem. 77 (2001) 1531-1541.

[41] M. Srivastava, N. Ahmad, S. Gupta, H. Mukhtar, Involvement of Bcl-2 and Bax in photodynamic therapy-mediated apoptosis. Antisense Bcl-2 oligonucleotide sensitizes RIF 1 cells to photodynamic therapy apoptosis, J. Biol. Chem. 276 (2001) 15481-15488.

[42] D. Kessel, M. Castelli, Evidence that bcl-2 is the target of three photosensitizers that induce a rapid apoptotic response, Photochem. Photobiol. 74 (2001) 318-322.

[43] C.M. Carthy, D.J. Granville, H. Jiang, J.G. Levy, C.M. Rudin, C.B. Thompson, et al., Early release of mitochondrial cytochrome $\mathrm{c}$ and expression of mitochondrial epitope 7A6 with a porphyrin-derived photosensitizer: $\mathrm{Bcl}-2$ and $\mathrm{Bcl}-\mathrm{xL}$ overexpression do not prevent early mitochondrial events but still depress caspase activity, Lab. Invest. 79 (1999) 953-965.

[44] A. Vantieghem, Y. Xu, W. Declercq, P. Vandenabeele, et al., Different pathways mediate cytochrome $c$ release after photodynamic therapy with hypericin, Photochem. Photobiol. 74 (2001) 133-142.

[45] M. Kato, T. Nonaka, M. Maki, H. Kikuchi, S. Imajoh-Ohmi, Caspases cleave the amino-terminal calpain inhibitory unit of calpastatin during apoptosis in human Jurkat $\mathrm{T}$ cells, J. Biochem. (Tokyo) 127 (2000) 297-305.

[46] Q. Peng, G.W. Farrants, K. Madslien, J.C. Bommer, J. Moan, H.E. Danielsen, J.M. Nesland, Subcellular localization, redistribution and photobleaching of sulfonated aluminum phthalocyanines in a human melanoma cell line, Int. J. Cancer 49 (1991) 290-295. 